\title{
OS VESTÍGIOS DA BIOGRAFIA EM O ATENEU, DE RAUL POMPEIA: AS MARCAS DE UM "PACTO AUTOBIOGRÁFICO"
}

\author{
RAUL POMPEIA BIOGRAPHY VESTIGES IN O ATENEU: MARKS OF AN \\ "AUTOBIOGRAPHICAL PACT"
}

\author{
Weslei Roberto CANDIDO \\ Universidade Estadual de Maringá \\ wrcandido@uem.br \\ Gabriela de Castro PEREIRA \\ Universidade Estadual de Maringá \\ gbrcp23@gmail.com
}

Resumo: O presente artigo tem por escopo explorar a tênue barreira entre ficção e realidade, buscando traços de um possível "pacto autobiográfico" (LEJEUNE,2014) entre o autor e o leitor, no enigma que se criou ao longo dos anos para saber se Sérgio, a personagem do romance $O$ Ateneu (1888), era 0 seu autor, Raul Pompeia. Sabe-se que a narrativa em questão é um texto ficcional. No entanto, é impossível negar a presença de traços autobiográficos do autor na construção do narrador-personagem da obra. Para explorar melhor esse caminho, traz-se para a discussão o conceito de "biografema" (BARTHES, 1978), na tentativa de elucidar como a ficção e a realidade se mesclam nessa narrativa híbrida, apontando para o fato de que a crise do romance, em fins do século $\mathrm{XIX}$, legou para a narrativa brasileira um texto que sobreviveria à morte do autor na crítica literária e ganharia novo fôlego com os estudos das autoficções, dos memorialismos, dos "biografemas" e recolocaria novamente a persona ficcional do autor no centro das discussões. Desta maneira, pretendese discutir como o romance em questão continua atual e se as relações entre a ficção e a realidade ainda constituem uma página em aberto na crítica literária a respeito do romancista.

Palavras-chave: Romance; Autobiografia; Memória; Raul Pompeia; Século XIX.

bstract: This paper has as scope to explore the tenuous barrier between fiction and reality, searching for traits of a possible "autobiographical pact" (LEJEUNE, 2014), between the author and the reader, on the enigma created over the years to know if Sérgio, character from the novel O Ateneu (1888), was its own author, Raul Pompeia. It is known that the narrative used is a fictional text. However, it is impossible to deny the presence of the author's autobiographical traits on first person narrator construction of the oeuvre. To explore better this situation, there is the discussion about the concept of "biographemes" (BARTHES, 1978), that tries to elucidate how fiction and reality are mixed on this hybrid narrative, pointing out to novel crises in the end of the $19^{\text {th }}$ century. That context forwarded to the Brazilian narrative a text that would survive to the death of the author on literature critics and would win a new breath with self-fictions studies, memorialism, "biographemes" and it would relocate again the author's fictional persona on the 
discussions center. Thus, it is tried to discuss how the novel in question continues current and the relations between the fiction and the reality still compose an open page in the literary critic on the novelist.

Key words: Novel; Autobiography; Memory; Raul Pompeia; 19th Century.

\section{Introdução}

A proposta do presente artigo é discutir as semelhanças biográficas que há entre a personagem Sérgio, de O Ateneu (1888) e o autor do romance, Raul Pompeia. Diante disso, acreditamos ser fundamental estudar a fundo a natureza dessas semelhanças e como elas podem configurar uma espécie de narrativa biografemática.

Embora os conceitos como "biografema", autoficção, narrativas do "eu" tenham surgido em época bem posterior à publicação do romance, eles auxiliarão na análise da narrativa. A possibilidade de analisar a obra do romancista por essas vertentes críticas mostram o quanto ainda há por se descobrir em $O$ Ateneu, que sobrevive ao tempo e ainda pode visto como um dos antecessores das narrativas que estão no limiar entre a ficção e a realidade.

Para Roland Barthes, o "biografema" é uma espécie de anamnésia ficcional, que leva o autor ao prazer da descoberta consciente de seu passado, sem aumentá-lo, nem diminuí-lo. O leitor encontra esse passado de maneira tênue, ao modo de um "haiku", uma nota vibrante que permanece no texto como uma impressão que dura, mas não toma o plano principal da narrativa:

\footnotetext{
Llamo anamnesia a la acción -mezcla de goce y de esfuerzo que ejecuta el sujeto para reencontrar, sin agrandarla ni hacerla vibrar, la tenuidad del recuerdo: es el haiku mismo. El biografema (ver SFL, 13) no es más que una anamnesia ficticia: la que adjudico al autor que me gusta (BARTHES, 1978, p.120).
}

Desta maneira, parte dos dados biográficos encontrados na narrativa em questão é também o resultado do esforço do leitor em reencontrar os traços da vida da pessoa do autor diluída na personagem Sérgio, não como nota dominante, mas como visita a pontos de luzes, que iluminam e explicam o passado. Essas pequenas iluminações mostram como a biografia e o romance podem compartilhar o mesmo espaço, sem com isso perder o seu caráter ficcional. 
Por isso, os "biografemas" também são formas de memória. A memória retomada em flashes, em pontos de iluminação efêmeros, que se assemelham ao fogo fátuo, mas que despertam a curiosidade do leitor. Essa é a sensação que temos ao ler $O$ Ateneu: os vestígios biográficos deixam rastros da infância do autor, que são inegáveis e, ao mesmo tempo, insuficientes para dar ao livro o caráter de autobiografia.

O Ateneu é uma espécie de prosa memorialística, que tem a personagem Sérgio como protagonista. Ele narra seus primeiros anos no colégio e sua separação da família. Nesse romance poderemos perscrutar como os traços biográficos ajudam a compor a diegese e, consequentemente, gerar dúvidas sobre o que é ficção e o que é biografia. Portanto, o presente estudo estará às voltas com a questão da prosa biográfica e romanesca, mostrando como essa linha tênue traz problemas para a interpretação do material ficcional.

No entanto, para compreender a densidade psicológica de Sérgio, como um canal que estreita os laços entre ficção e realidade, devemos entender a formação do pensamento crítico do jovem autor, que buscava justiça em meio a um Brasil prestes a contemplar a abolição da escravatura e a Proclamação da República. Pompeia foi jornalista e cartunista, tecendo inúmeras críticas ligadas aos movimentos revolucionários da época.

\section{Objetivos}

A presente pesquisa, a partir do estudo de O Ateneu, pretende encontrar vestígios autobiográficos da vida de o autor de As joias da coroa e os possíveis motivos que o levaram a optar por expor fatos de sua vida, utilizando a personagem Sérgio. Acredita-se que o narrador autodiegético tenha fortes relações com a vida de Pompeia, cuja figura histórica apresenta uma série de coincidências com o protagonista do romance.

Por ello, sólo se encontrarán aquí, mezcladas con la novela familiar, las figuraciones de una prehistoria del cuerpo, de ese cuerpo que se encamina hacia el trabajo, hacia el goce de la escritura. Pues es este el sentido teórico de esta limitación: manifestar que el tiempo del relato (de la imaginería) termina con la infancia del sujeto: no hay biografía 
más que de la vida improductiva. En cuanto produzco, en cuanto escribo, es el Texto mismo el que me desposesiona (afortunadamente) de mi duración narrativa. El Texto no puede contar nada; se lleva a mi cuerpo a otra parte, lejos de mi persona imaginaria, hacia una suerte de lengua sin memoria, que es ya la del Pueblo, la de la masa insubjetiva (o sujeto generalizado), aunque yo siga estando separado de él por mi manera de escribir (BARTHES, 1978, p.09-10).

Em Roland Barthes por Roland Barthes, o autor ficcionaliza sua própria vida, tornando-se ele mesmo objeto da narrativa. Espécie de romance familiar, seu texto traz uma pré-história do corpo, que se revela no gozo do próprio ato de escrever. O romance de Raul Pompeia, ao modo da teorização de Barthes, que vê no tempo limitador da infância o término da imaginação, também pode ser interpretado nesses termos: pelo gozo da escrita, por deixar vazar na materialidade do tecido textual o protesto contra os apagamentos do tempo, por meio de uma linguagem objetiva, que o desapossa da biografia, por meio da língua que é impessoal e de todos, mas que ao mesmo tempo purga o autor de sua duração narrativa, para transportá-la ao nível da ficção, do romance, onde o estilo da linguagem o afasta dos signos verbais genéricos da coletividade, para sua individualização, via estilo escritural. É por isso que em O Ateneu, a narrativa "deixou vazar", segundo Mário Andrade (1943, p.173), a sua vingança contra o colégio Abílio, de modo a fazer do romance uma denúncia castigadora. No campo da ficção, a vingança contra os males da infância se tornava possível e executável.

Assim, pode-se afirmar que o romance de Raul Pompeia também é uma "heterobiografia". Como afirma Antonio Candido (1989, p.56): "A experiência pessoal se confunde com a observação do mundo e a autobiografia se torna heterobiografia, história simultânea dos outros e da sociedade [...]". O Ateneu, como romance autobiográfico, faz com que o olhar de Sérgio/Raul Pompeia(?), também traga consigo uma forma de interpretação do universo infantil nos colégios internos, tornando a experiência pessoal em apelo universal das crises e dramas enfrentados na separação familiar, que dá ingresso a uma nova etapa da vida; fator, talvez, irreconciliável para muitos.

Para debater a problemática do romance, do romance biográfico ou do romance de memórias de Raul Pompeia, a teoria do "pacto autobiográfico", de 
Philippe Lejeune (2014), será utilizada como fundamentação teórica. Assim, será possível estudar o romance, levando em conta os "biografemas" inseridos nele, que Barthes (1978, p.9) considera ser um amigável regresso ao autor. O escopo da presente pesquisa, portanto, será o estudo dos diversos níveis de "regressos" de Raul Pompeia autor ao Sérgio persona ficcional em O Ateneu.

\section{Raul Pompeia: caminhos biográficos}

Segundo Oliveira (2000, p.196), "Raul d'Ávila Pompeia nasceu em Jacuacanga, atual $3^{\circ}$ distrito de Angra dos Reis. Aos 10 anos, seguiu com a família para a cidade do Rio de Janeiro, onde o pai, um abastado advogado, resolvera-se estabelecer". Nesse momento, "em 1873, vamos encontrar o menino Raul matriculado na terceira série do internato Colégio Abílio, um dos mais importantes estabelecimentos de ensino da Corte" (CAPAZ, 2001, p.14).

Raul Pompeia foi um menino que veio de uma cidade do interior. Aos 10 anos entrou em contato com uma experiência totalmente nova: ingresso em um colégio interno. Algo que o futuro autor, naquela idade, não poderia dimensionar o impacto que isso acarretaria sobre a formação de seu caráter. Além disso, tinha um pai rico exercendo a advocacia. Na época, era comum que o filho herdasse os negócios do pai, e possivelmente, por esse motivo:

\footnotetext{
[...] em princípios de 1881, mudou-se para São Paulo, para cursar Direito na Faculdade de Direito do Largo de São Francisco, época em que 0 ambiente acadêmico fervia com as campanhas abolicionistas e republicanas. [...] Ele e mais 93 colegas foram reprovados no $4^{\circ}$ ano da faculdade por perseguição ideológica de um professor. Todos em protesto foram para o Recife concluir o curso. Raul Pompeia nunca usou o seu diploma (OLIVEIRA, 2000, p.196).
}

Quanto a essa parte da vida do autor, percebe-se que romancista começou seguindo os passos do pai ao ingressar no curso de Direito. Porém, ele entrou em contato com as revoluções prestes a eclodirem no país, cujas ideologias se disseminavam no ambiente acadêmico. Com isso, o romancista adotou posicionamentos que fizeram a faculdade voltar-se contra ele e seus colegas, mas isso não os impediu de se formarem. Possivelmente, devido às 
ideologias com as quais entrou em contato, o autor não se viu como um futuro advogado, mas, mesmo assim, concluiu o curso. No entanto, o horizonte de atuação de Raul Pompeia se desenhava bem diferente da carreira jurídica:

[...] no segundo e terceiro anos da faculdade, foi intensa sua colaboração nos jornais Gazeta do Povo, Correio Paulistano, A Idéia, Çà Ira e Jornal do Comércio, folha que dirigiu com o amigo Gaspar da Silva, fora dos muros da faculdade. Era terrível sua veia panfletária, nos artigos que publicou nessa época, que se destacam pelo sarcasmo e pela extrema agressividade (CAPAZ, 2001, p.43).

Assim, Pompeia, depois de formado, começou a trabalhar como jornalista e cartunista.

Em 1892, houve o "famoso [...] embate com Olavo Bilac por divergências políticas. Ambos não se bateram num duelo porque seus padrinhos os fizeram ver que seria uma estupidez" (OLIVEIRA, 2000, p.196). Afeito a polêmicas, o romancista, profundo admirador de Floriano Peixoto, no velório do marechal, fez um discurso acalorado e que foi mal compreendido por muitos, levando-o à futura demissão por Prudente de Morais:

Pouco antes, no enterro de Floriano Peixoto, fizera um discurso emocionado para o velho marechal. Tão emocionado que motivou uma crítica pública de Luís Murat, sob o título "Um Louco no Cemitério" [...] Homem de sensibilidade extrema, Raul Pompeia abateu-se com a crítica. Escreveu duas respostas violentas ao ataque de Murat, mas nenhum dos dois jornais de que era colaborador quis publicá-las. Abatidíssimo, o escritor foi para a casa onde estavam sua mãe e sua irmã.

Era Natal de 1895, ele não pôde mais. Suicidou-se com um tiro no coração (OLIVEIRA, 2000, p.196).

O romancista foi um homem de temperamento exaltado e febril, o que 0 levou a uma produção enorme para a pouca idade que tinha: "Raul Pompeia (1863-1895) escreveu cerca de 64 textos sobre artes plásticas ao longo dos anos 1880 e 1893, datas que cravam a primeira e última vez que o escritor se dedicou ao assunto" (PELK, 2016, p.305). Sendo que “O Ateneu, cujo subtítulo é Crônica de Saudades, começou a ser publicado em folhetos no jornal Gazeta de Notícias, quando o autor contava com apenas 25 anos" (OLIVEIRA, 2000, p.196). 
Os anos acadêmicos iniciais do futuro autor demonstram que, apesar de no período da graduação ter se mostrado um jovem determinado a fazer justiça, o autor se viu devastado com a censura dos jornais. Esse possível isolamento da imprensa pode ser uma das prováveis causas que o levaram a cometer suicídio no Natal, na mesma casa em que estavam sua mãe e sua irmã, vigiandoo para que não fizesse uma loucura. $O$ fato de ter sido acusado de covarde, na ocasião do duelo com Bilac, nunca fora bem digerido. O romancista tornou a situação ainda mais melodramática, e poética, ao mesmo tempo, dando cabo de sua vida com um tiro no coração.

Diante dessa atitude surgiram muitas perguntas: Mas por que o coração e não a cabeça? O que será que Pompeia carregava no peito que lhe pesava tanto para fazer com ao se matar, acionasse o gatilho na direção do coração?

De acordo com alguns amigos, poucos dias antes da morte de Raul Pompeia, ele fora surpreendido pelo suicídio de um músico italiano, que levava sua arte pelas ruas. Ao chegar à casa do morto, vira que o homem se matara com um tiro na cabeça. Saiu da casa transtornado e certo de que aquele senhor não era um artista: na verdade, um homem das artes jamais se mataria com um tiro na cabeça, nela estão todos os conceitos, todas as ideias; é da cabeça que saem as produções de valor. Talvez, ali, naquele momento, o ainda jovem artista tenha definido o modo pelo qual poria fim a sua vida: um tiro no peito, preservando, assim, a cabeça, o centro das ideias. Sendo fiel às crenças que propagava, o romancista aplicou o método que julgava o mais artístico possível para encerrar a vida.

Rodrigo Octavio registra que:

Não era propriamente o fato do suicídio que o preocupava. Ele compreendia o suicídio, que era, em última análise, uma solução; boa ou má, porém uma solução e que, ao menos para quem a encontra, dirime todas as dificuldades, paga todos os sofrimentos.

O que Pompeia não admitia é que o animal inteligente e consciente se deformasse, quebrando por vontade própria, o complexo harmônico de linhas e formas que constituem a cabeça. Ser belo sempre belo, mesmo depois de morto, enquanto a contemplação do morto se permite aos vivos.

É preciso guardar a ilusão até o fim, até para depois de nós. Além disso, é preciso ainda respeitar a cabeça, a sede superior dos predicados intelectuais. $\mathrm{O}$ homem vive pelo cérebro. Quando o cérebro se enfraquece ou morre, o homem diminui e torna-se ridículo. Nunca 
ferir o cérebro. O coração que é o centro da vida animal. É pelo coração que a morte deve ser buscada (OCTAVIO, 2016, p. 55 apud COUTINHO).

Vê-se, por esse longo fragmento retirado do depoimento de Rodrigo, amigo pessoal do escritor, que o romancista tinha o suicídio como uma saída. $\mathrm{Na}$ verdade, reprovava ao italiano apenas o fato de ter danificado a cabeça com o tiro. Para Pompeia o cérebro era o centro da vida do homem, a verdadeira beleza estava na cabeça, por isso, mesmo ao se matar o corpo deve ser uma representação para os vivos do que foi o morto que ali jaz. Talvez, por esse motivo, o romancista tenha tirado a vida por meio de um tiro no peito. A cabeça foi preservada e seu conceito de belo também. Até na hora da morte, Raul Pompeia foi um artista.

\title{
O Ateneu
}

O Ateneu narra história do jovem Sérgio desde o seu ingresso no colégio interno, até o momento em que o lugar é destruído por um incêndio. "É uma narrativa de arte, a fábula do menino que se perdeu nos caldeirões infernais (simplesmente por ter vindo à vida e ingressado na escola) e que se lembra, em meio à interminável agonia, da salvação que a Arte pode representar" (MOISÉS, 1985, p.131).

\begin{abstract}
A arte significa a alegria do movimento, ou um grito de suprema dor nas sociedades que sofrem. Entre nós, a alegria é um cadáver. Ao menos se sofrêssemos... A condição da alma é a prostração comatosa de uma inércia mórbida. Quem nos dera a tonicidade letal de uma vasca (POMPEIA, 1996, p.53).
\end{abstract}

O autor de maneira poética expressa como a arte motivava a sua existência, sendo a expressão daquilo que Ihe dava forças para lidar, dia após dia, com o "inferno" que era o Ateneu. Diante desse quadro, Massaud Moisés (1985, p.132) conclui, a partir de um breve esquema, que O Ateneu pertence à literatura, logo, pertence à arte. Assim, sua escrita foi o que impulsionou a vida de Pompeia. Vale lembrar que, como foi a arte que "salvou" o autor, não foi apenas a escrita que possibilitou esse feito, pois o romancista também fez um 
grande uso da arte visual em suas críticas, e suas obras, assim como é o caso d'O Ateneu.

Na obra original, o escritor fez ilustrações de partes da história. A primeira é justamente a que exprime a cena inicial, na qual o pai diz a Sérgio: "Vais encontrar o mundo, disse-me meu pai, à porta do Ateneu. Coragem para a luta"

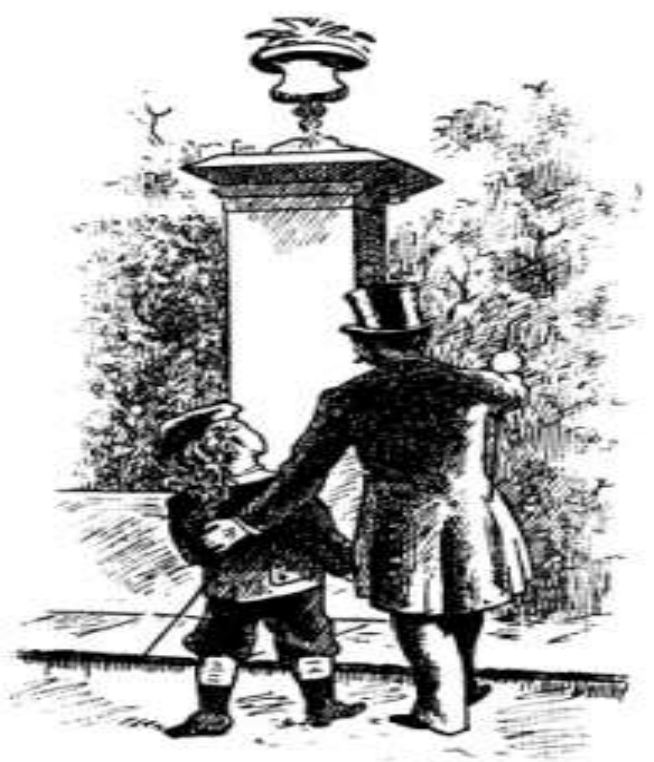

(POMPEIA, 1996, p.1).

Fig. 1 Chegada de Sérgio ao Colégio.

Até hoje, não foi possível comprovar se realmente o pai de Pompeia lhe fez essa assertiva, quando o levou ao internato masculino. No entanto, é provável que, se essa cena aconteceu com o autor, na vida real, assim como o "inferno psicológico" que foi o Ateneu para Sérgio, as primeiras palavras do pai, às portas do colégio, foram marcantes. Uma vez que elas parecem não ser apenas uma simples motivação a Sérgio, mas também estão carregadas de conhecimento do que o menino iria passar. Diante disso, pode-se cogitar que nesse episódio há presente uma "introspecção autobiográfica", conforme denomina StegagnoPicchio (2004, p.424). Por isso, há a possibilidade de essa cena ser um artifício para a intromissão do narrador na obra, a partir das primeiras palavras do romance, advindas da fala do pai. Como uma forma de indicar ao leitor a perspectiva de uma luta. Outro trecho a ser destacado é:

"Como se chama o amiguinho?" perguntou-me o diretor. 
— Sérgio... dei o nome todo, baixando os olhos e sem esquecer o "seu criado" da estrita cortesia.

- Pois, meu caro Sr. Sérgio, o amigo há de ter a bondade de ir ao cabeleireiro deitar fora estes cachinhos... Eu tinha ainda os cabelos compridos, por um capricho amoroso de minha mãe. O conselho era visivelmente salgado de censura. $O$ diretor, explicando a meu pai, acrescentou com o risinho nasal que sabia fazer: "Sim, senhor, os meninos bonitos não provam bem no meu colégio..." (POMPEIA, 1996, p.8).

Pode-se observar, acima, o primeiro diálogo entre Sérgio e o diretor Aristarco, em que o mesmo censura o comprimento do cabelo do futuro aluno do colégio. O leitor ao observar a primeira ilustração do romance, notará que a melena chegava à cintura do menino. A partir desse momento, constata-se que Aristarco, aos olhos de Sérgio, tem uma maneira intimidadora de educar que, apenas acanha, mas não conquista seus alunos.

Nesse momento, surge pela primeira vez a figura de D. Ema, também ilustrada por Pompeia, que, ao contrário de seu marido, Aristarco, mostra-se gentil e maternal, quanto à situação do corte de cabelo de Sérgio

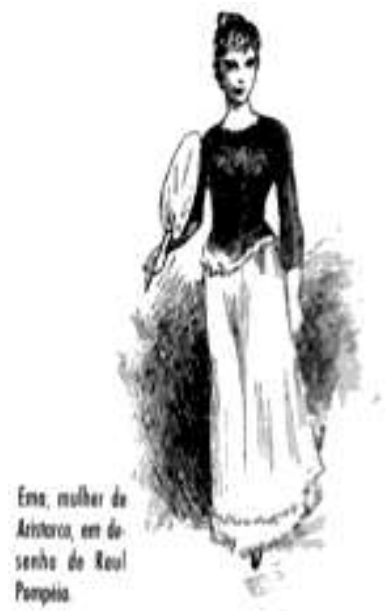

Fig. 2 Imagem de Ema feita por Pompeia

- Corte e ofereça à mamãe, aconselhou com uma carícia; é a infância que ali fica, nos cabelos louros... Depois, os filhos nada mais têm para as mães (POMPEIA, 1996, p.8).

É possível notar que há semelhanças entre Sérgio e escritor. Uma delas é o fato de ambos terem estudado no mesmo tipo de colégio, apesar de na biografia do autor, Capaz afirmar que é "equivocado [...] dizer-se que o Ateneu é 
apenas o Colégio Abílio, [...] por seu turno, foram tirados de sua vivência fora da escola e também dos seus tempos no externato Colégio Pedro II" (2001, p.15).

Há também a questão da representação do diretor.

Sob direção de Abílio César Borges, o barão de Macaúbas, era um colégio muitíssimo procurado em razão dos métodos avançados que aplicava na instrução dos jovens e do alto nível do seu corpo docente. Seu diretor gozava de grande prestígio desde os tempos em que fundara o seu primeiro estabelecimento, em Salvador, e também por seus livros didáticos grandemente utilizados nas escolas da corte e do resto do país (CAPAZ, 2001, p.14).

Diante dessa descrição, pode-se ver claramente a coincidência com a figura de Aristarco, diretor do Ateneu, descrito por Sérgio:

O Dr. Aristarco Argolo de Ramos, da conhecida família do Visconde de Ramos, do Norte, enchia o império com o seu renome de pedagogo. Eram boletins de propaganda pelas províncias, conferências em diversos pontos da cidade, a pedidos, à substância, atochando a imprensa dos lugarejos, caixões, sobretudo, de livros elementares, fabricados às pressas com o ofegante e esbaforido concurso de professores prudentemente anônimos, caixões e mais caixões de volumes cartonados em Leipzig, inundando as escolas públicas de toda a parte com a sua invasão de capas azuis, róseas, amarelas, em que o nome de Aristarco, inteiro e sonoro, oferecia-se ao pasmo venerador dos esfaimados de alfabeto dos confins da pátria. Os lugares que os não procuravam eram um belo dia surpreendidos pela enchente, gratuita, espontânea, irresistível! (POMPEIA, 1996, p.2).

\section{Entretanto, Brandão (1988) coloca que}

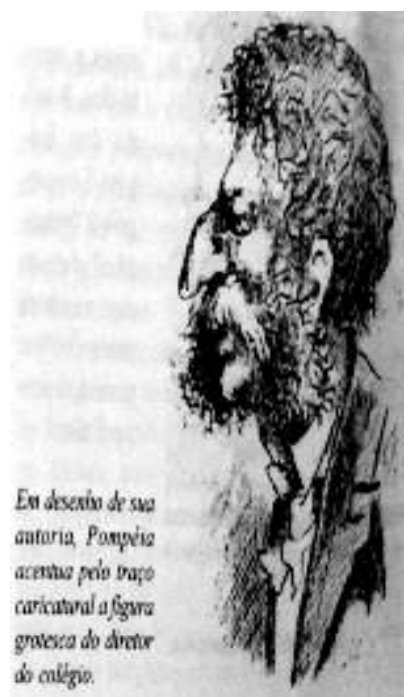


Fig. 3 - Caricatura de Aristarco feita pelo romancista.

Ele e Sérgio, a personagem-narrador, foram os dois pólos do romance: o primeiro simboliza a cristalização dos valores estabelecidos, e o segundo representa a transformação psíquica e emocional do jovem que vai penetrando na crua realidade da vida, de que o colégio é o espelho (BRANDÃO, 1988, p.50).

Nota-se, assim, que não há consenso entre o crítico e o biógrafo em considerar que todos os episódios narrados em $O$ Ateneu sejam a síntese do que Raul Pompeia viveu. Mas, é importante ressaltar que o diretor Aristarco foi retratado como um homem soberbo, cujo único foco é o dinheiro, e não demonstrava ter preocupação com o bem-estar dos alunos do colégio. Ele também é o responsável pelo "inferno psicológico", que Sérgio passa durante a sua estadia no Ateneu. Assim, é possível entender que Aristarco, se ele realmente se erigiu como uma representação do Barão de Macaúbas, era um homem que não esboçava amor ao ser humano, sendo apenas mais um mercador que cedeu ao capitalismo, utilizando-o ao seu favor.

No entanto, o diretor pode ser uma estratégia utilizada pelo narrador para transformar Aristarco em um mecanismo representativo das tribulações que acarretam o amadurecimento do protagonista. Sérgio, uma vez retirado do seu "refúgio placentário" (STEGAGNO-PICCHIO, 2004, p.424), é lançado pelo pai para ir à luta e conhecer o mundo. Esse menino, lançado ao universo do Ateneu, chega totalmente inocente, e logo de início é coagido pelo diretor a cortar o cabelo; tal fato, segundo D. Ema, é o marco do fim da infância. A partir disso, pode-se pressupor que Aristarco seja uma metáfora que simboliza o amadurecimento, somado a todas às situações desagradáveis que a vida proporciona a cada indivíduo pertencente ao sistema sócio-capitalista. Fazendo com que:

[...] a interioridade de Sérgio, narrador do romance, prova ser semelhante à do diretor, o grande escarnecido de O Ateneu. Aristarco é a condição humana implicada no romance, onívora, que devora seu próprio narrador. É somente neste ponto, engolindo-se, que O Ateneu revela seu sentido pleno; fechado sobre si mesmo dá sua própria interpretação. Violência com pés de barro, sua ferocidade não é distância (SCHWARZ apud COUTINHO, 2016, p.240) 
Há também a questão do subtítulo, Crônica das Saudades, que não pode ser ignorado diante da finalização do romance, pois, mostra uma densidade emocional advinda de uma carga sentimental intensa: "Aqui suspendo a crônica das saudades. Saudades verdadeiramente? Puras recordações, saudades talvez, se ponderarmos que o tempo é a ocasião passageira dos fatos [...] funeral para sempre das horas" (POMPEIA, 1996, p.114). Tem-se a impressão de sinceridade, que aparenta ir além da expressa por Sérgio, por isso, a ideia da mescla da figura histórica de Pompeia à figura do protagonista do romance não pode ser descartada.

Diante dessa situação, é interessante notar que esse fragmento descreve as práticas políticas do colégio: "Toda a crônica obscura do Ateneu redigia-se ali, em termos explícitos e fortes, expurgada dos arrebiques de recato, de inverdade, pelo escrúpulo das comissões investigadoras" (POMPEIA, 1996, p.92). Essa é a única vez que, além do final do último capítulo, o narrador se refere a'O Ateneu como uma crônica das saudades. Nesse excerto é possível observar o escárnio utilizado por Sérgio para se referir ao estabelecimento de ensino; porém, o mais interessante é que o "Ateneu" se encontra grafado em itálico, como se utiliza ao se denominar uma obra. Então, há uma ambiguidade, uma vez que Ateneu pode ser o colégio interno, ou a obra redigida por Raul Pompeia. Sendo assim, o narrador pode estar se referindo ao local, portanto, afirmando que a Crônica das saudades pertence ao colégio interno, ou que é sobre o mesmo; ou ainda, à obra, O Ateneu, era redigida no local em que Sérgio, narrador-personagem, estava: o colégio interno.

Diante de tantas indagações, Ribeiro (2006, p.134) coloca que há uma "dissociação irônica" entre Pompeia e Sérgio. Segundo o autor, há a centralização da subjetividade, de maneira impressionista, ao explorar o ponto de vista interno de Sérgio. Deve-se levar em conta a assimetria temporal que há entre o "Sérgio-personagem", uma criança, e o "Sérgio-narrador", um adulto, cuja motivação da escrita do romance seria "a revolta devido aos ideais corrompidos [que] revela ao leitor a crise da visão de mundo que eles susteram" (SILVA, 2001, p.27). Algo que equivale à vida do escritor, visto ter sido ele um jornalista que mostrou um posicionamento crítico firme, nunca se calando mediante algo que 
considerava errado. É a partir da atuação de Pompeia como jornalista, que o romance $O$ Ateneu pode ser lido como a manifestação da indignação do autor, de maneira indireta.

\section{A Classificação d'O Ateneu}

Segundo uma das notas de Raul Pompeia, exposta por Pontes (1935, p.18), ele acreditava que para uma obra ser completa, ela precisava ser composta por traços da personalidade do escritor; esses elementos trariam vida à obra. A partir dessas notas, pode-se inferir, talvez, que o romancista considere os caracteres biográficos como uma maneira de trazer mais naturalidade ou verossimilhança ao texto. Mediante a isso, pode-se considerar que:

[...] Raul Pompeia, inventor plástico, modelou as sequências da obra não como simples elos de uma cadeia temporal, mas como se cada episódio abrigasse em si um viveiro de figuras em plena arborescência. Daí vem uma saturação estilística [...] (BOSI, 2010, p.51 - 52).

Frente ao exposto, arriscar uma classificação de $O$ Ateneu é uma tarefa que exige cautela, pois ao mesmo tempo em que a obra pode ser lida apenas como romance, é inegável que haja semelhanças entre Raul Pompeia - homem pertencente ao mundo real - e o narrador-personagem - ser de papel (DUCROT \& TODOROV, 1974, p.259) - da obra. Nesse caso, levando em consideração tudo o que já foi discorrido, pode-se reafirmar que há "biografemas" (BARTHES, 1978, p.9) da vida do autor na narrativa, ou seja, há traços de sua vida, vivenciados pela personagem Sérgio n'O Ateneu.

São os "biografemas" presentes no romance que permitem uma leitura biográfica da obra. Ao mesmo tempo, os "biografemas" são intromissões assíncronas temporalmente, desordenados, chamados pela reminiscência, em momentos cruciais do romance. Provavelmente, os instantes críticos de Sérgio na narrativa são os que mais carregam a personalidade do autor. Por isso, os "biografemas" iluminam momentaneamente o passado de Pompeia, por meio das aventuras de Sérgio, mas o fazem tão rapidamente que não retiram o romance do seu plano ficcional. 
Apropriando-nos do que Antonio Candido comenta sobre a tendência ao biografismo presente na gênese da literatura brasileira é possível ler o substrato da autobiografia presente em O Ateneu:

[...] reversivelmente como recordação ou como invenção, como documento da memória ou como obra criativa, numa espécie de dupla leitura, ou leitura "de dupla entrada", cuja força, todavia, provém de ser ela simultânea, não alternativa (CANDIDO, 1989, p.54).

Essa dualidade do romance $O$ Ateneu faz dele uma narrativa múltipla em seus sentidos, podendo ser lido ora como romance, ora como romance biográfico ou autobiográfico, ora como memória. Porém, nunca poderá ser lido isoladamente dentro de uma dessas características. O jogo entre realidade e ficção, memória e ficção, biografia ou romance autobiográfico constituem a riqueza da obra de Raul Pompeia. E é lido em chave de simultaneidade que o leitor encontrará a profundidade psicológica de Sérgio, nesse aspecto esquizofrênico de ser personagem e ser representação de Pompeia.

Philippe Lejeune propõe como elemento central de sua teoria do "pacto autobiográfico", para considerar um texto como autobiografia, a seguinte equação: "autor = narrador e autor = personagem" (2014, p.26). De modo que o nome de autoria, que é destaque na capa da publicação, deve coincidir em totalidade ao nome do narrador autodiegético presente no texto. Portanto, só seria uma autobiografia os textos que respeitassem essa fórmula. Exceção que se abre às narrativas que apresentem um "eu" narrador, que mesmo inominado, não deixe dúvidas de sua identidade ser a mesma do autor da capa. Essa prática de escrita é que leva ao "pacto autobiográfico" entre autor e leitor. Aquele que lê, aceita a coincidência em sua totalidade, autor=narrador autodiegético, autor=personagem (nominado ou não).

Por esse viés, O Ateneu não é uma autobiografia, seria, antes, um romance autobiográfico, uma vez que não há a coincidência entre o nome do autor do livro e o nome do narrador-personagem. As semelhanças são encontradas, ao que se pode constatar, apenas nos vestígios biográficos, pertencendo a obra de Raul Pompeia, portanto, ao campo da ficção. 
Entretanto, a nomenclatura "Autobiografia em terceira pessoa" é um tanto incoerente, visto que o termo "auto" remete a si mesmo, e não a uma terceira pessoa. Então, Lejeune (2014) propõe enquadrar esses textos na classificação de "romance autobiográfico":

[...] Chamo assim todos os textos de ficção em que o leitor pode ter razões de suspeitar, a partir das semelhanças que acredita ver, que haja identidade entre autor e personagem, mas que o autor escolheu negar essa identidade ou, pelo menos, não afirmá-la (LEJEUNE, 2014, p.29).

Há a classificação de "ficção autobiográfica", também de Lejeune (2014), porém essa não se adéqua a'O Ateneu, visto que, para ela acontecer, é preciso que seja narrada com base mais extensa na vida do autor. Esse não é procedimento narrativo usado na obra de Pompeia, na qual o Ateneu não corresponderia, na vida de Pompeia, ao Colégio Abílio, sobretudo porque o autor estudou em mais de um colégio, no período equivalente ao que Sérgio estudou em uma única instituição o que, de fato, altera em muito a experiência, ou os sofrimentos, da personagem.

Fábio Lucas em "As várias faces de Raul Pompeia e O Ateneu", comenta justamente os flertes do romance de Pompeia com outros gêneros, não sendo uma "autobiografia" e transitando entre vários gêneros, o que aponta para a crise do romance no final do século XIX e ao mesmo tempo para o caráter híbrido dessa narrativa. A crise de Pompeia é a própria crise do romance:

Raul Pompeia em O Ateneu combina literatura pessoal com literatura de testemunho. Entretece os domínios do discurso da ficção com os da memória, os da informação educativa e os da exposição científica. Na leitura do romance, ora se denuncia o pacto autobiográfico, ora não. Tomando um mundo vivido como fonte mistura confissão com profissão de fé.

O romancista opera uma visão desnudante, num relato retrospectivo em primeira pessoa (LUCAS, 1995, p.20).

Por isso, todas as vezes que tentaram classificar o romance O Ateneu, fracassaram. Como obra de discursos híbridos, a narrativa em primeira pessoa flerta com o passado biográfico do autor, mas ao mesmo tempo se singulariza como ficção de cunho romanesco, com traços memorialísticos do passado 
brasileiro e do autor. $\mathrm{O}$ fato é que $O$ Ateneu se consolida como exemplar único de uma prosa perscrutadora de um passado, que é em sentido amplo, o próprio motivo do romance no Brasil.

\section{O Ateneu: um romance}

A criação no romance é uma tarefa que passa pela personalidade do autor, é ele quem dá corpo à sua criação, às suas personagens. A organização verbal a que submete o discurso romanesco, faz do autor um demiurgo, um criador de mundos que podem partir da realidade ou da lembrança que esse tem da realidade. O romance é sempre representação. O trabalho verbal modifica os ambientes, as pessoas históricas e dá coerência a atos e atitudes que, no conjunto da obra, conformam seus personagens como elementos completos, dando-nos a sensação de que conhecemos os personagens em sua completude e, consequentemente, um pouco de seu autor.

De acordo com Forster:

[...] O romancista, [...] arranja uma porção de massas verbais, descrevendo a grosso modo a si mesmo (a grosso modo, as sutilezas virão mais tarde), dá-lhes nomes e sexos, determina-lhes gestos plausíveis e as faz falar por meio de aspas e talvez comportarem-se consistentemente. Essas massas verbais são suas personagens. Elas não chegam assim frias à sua mente, podendo ser criadas em delirante excitação. [...] Qual é a diferença entre as pessoas num romance e as pessoas como o romancista ou como vocês?, ou como eu, ou como a Rainha Vitória?

Há uma diferença obrigatória. Se uma personagem num romance é igual à Rainha Vitória - não parecida, mas exatamente igual, então de fato é a Rainha Vitória e o romance ou toda a parte dele que aludir a esse personagem, torna-se-á uma Memória. Uma mémoire é história, é baseada nos fatos. Um romance é baseado nos fatos + ou - $\mathrm{x}$, sendo a incógnita o temperamento do romancista, essa incógnita sempre modifica 0 efeito dos fatos e, algumas vezes, os transforma inteiramente (FORSTER, 1974, p.34-35).

A partir da discussão de Forster sobre o trabalho do romancista, pode-se compreender que Raul Pompeia mesclou em O Ateneu memória e ficção, ora narrando "biografemas" de sua vida, ora narrando como memória, o passado de Sérgio. O autor tornou possível que o leitor veja em Sérgio um alter ego de Raul 
d'Ávila Pompeia. O uso dos "biografemas" (BARTHES, 1978, p.9) deu ao romance uma narrativa híbrida, entre a ficção e a memória, a memória e a história de vida pessoal e, em alguns momentos, plasmou nessa crise, a própria crise romanesca do material que lhe serviu de base para moldar o mundo ficcional. Assim, não é possível afirmar que a obra é uma biografia, uma vez que Pompeia não se coloca explicitamente no romance, e também como não é possível discernir o que realmente aconteceu ou não na vida do autor, o romance se consolida ao final da narrativa, romance familiar, romance de memórias.

Segundo Georg Lukács (2000, p.83), o romance na forma biográfica supera a má infinitude, trazendo sentido a sua vida, em uma trajetória para o autoconhecimento, articulando cada elemento à personagem central "e ao problema vital simbolizado por sua biografia".

Ao levar em consideração a afirmação de Lucien Goldmann de que: "[...] o romance é, necessariamente, biografia e crônica social, ao mesmo tempo" (1976, p.12). Pode-se recordar que Raul Pompeia dá o subtítulo para seu romance de Crônicas das Saudades. É curiosa a coincidência, mas muito elucidativa na situação d'O Ateneu, visto que a obra é um romance com traços da biografia do autor, "biografemas", e também é denominado uma crônica, pelo narrador. Essa denominação de crônicas pode ser entendida como a presença constante do autor imiscuído na diegese. O trabalho do cronista supõe o envolvimento pessoal na história que conta. Por esse ângulo, podemos pensar que, em certa medida, Sérgio é uma máscara de Raul Pompeia na narrativa. $O$ autor a utiliza para lançar luz sobre seu passado, para entender a vida no colégio interno e faz do inferno de Sérgio, o inferno de todo garoto que tem de abandonar a família para estudar no regime de internato. Inferno, que o romancista também enfrentou. Nesse sentido, o romance é a crônica de todo rapaz que teve de passar por essa experiência e nisso reside a universalidade de $O$ Ateneu, fazendo com que o romancista pratique uma espécie de "heterobiografia", para usar a linguagem de Antonio Candido.

\section{Considerações Finais}


Após termos percorrido este longo caminho na tênue linha entre ficção e realidade, memória e literatura, biografia e romance biográfico, podemos concluir que Raul Pompeia preferiu expor episódios de sua infância por meio de "biografemas" n'O Ateneu. Assim, não comprometeu a sua identidade histórica, uma vez que os "biografemas" podem ser uma forma de dar um caráter ambíguo à narrativa, obrigando o leitor a um esforço maior de intepretação, deixando-o na incerteza sobre o gênero que tem em mãos.

Porém, isso não faz da obra uma autobiografia: mas, um romance autobiográfico como tentamos provar ao longo do artigo. A despeito do hibridismo da narrativa composta por Pompeia, o resultado final permite classificá-lo dentro do âmbito da ficção, faltando à narrativa elementos que permitam enquadrá-la como autobiografia. Segundo Edwin Muir "O fato de que o romancista escreva sobre a vida não é assim tão extraordinário: é a única coisa de que ele tem conhecimento" (1975, p.12). Portanto, utilizar a própria vida como motivo inspirador, como ponto de partida para a produção de um romance dentro de todas as distorções que esse opera sobre a realidade, não é algo tão incoerente afinal.

\footnotetext{
O dado original da ruptura foi matriz de infelicidade para o adulto. Raul Pompeia-Sérgio não perdoou à vida o ser lançado à indiferença cruel da escola, e à sociedade com os mais fortes. O seu único momento de abandono virá tarde, quando Ema o acarinha, convalescente, isto é, quando o sacrifício da vida social, competitiva e má, é posto de lado para não mais voltar. À cura de Sérgio se seguirá o incêndio da escola, fecho do romance. Também o suicida Pompeia não aceitou o fardo excessivo que the impunham as palavras do pai - "Coragem para a luta". O ato de incendiar o colégio é homólogo ao suicídio: um e outro significam uma recusa selvagem daquela vida adulta que começa no internato.

A descrição da experiência colegial é feita em termos de requisitório: a criança que subsiste no homem é o promotor e, vantagem do romancista, pode ser também o juiz final, manipulador do apocalipse. No primeiro plano de ataque, a fachada composta e brilhante do processo educativo, onde se pode ver em miniatura o decoro das instituições do Império que o ardente republicano Raul Pompeia então combatia (BOSI, 1999, p.185).
}

Quando o pai de Sérgio o diz nas primeiras linhas d'O Ateneu "Coragem para a luta" (POMPEIA, 1996, p.1), abrem-se as portas para uma jornada de autoconhecimento, que Raul Pompeia/Sérgio precisava desempenhar sozinho, 
para, por fim compreender a matriz da sua infelicidade. Porém, ele só fez essa autoanálise quando adulto. A partir dela pôde rememorar o início traumático da sua imersão social, que era vista, por Raul Pompeia/Sérgio, como opressora e desagradável, a cada momento. A única que não o fazia se sentir assim no colégio era D. Ema, que era o oposto do diretor Aristarco, o qual se mostrou uma figura opressora desde o primeiro capítulo, e que no último é apresentado de maneira abatida, mostrando que a narrativa d'O Ateneu atingira seu objetivo de vingança contra o colégio e seu diretor. Apenas quando o Ateneu findou em chamas, é que Raul Pompeia/Sérgio veio a ter um alívio, ainda que não a cura, do contato com a sociedade doente com a qual conviveu.

Se o Ateneu pode ser considerado o Colégio Abílio, uma instituição do Império brasileiro, como afirma Bosi, cuja estrutura social e política estava em decadência, devido aos movimentos favorecedores à República - dos quais Pompeia era um membro atuante -, proclamada um ano após a publicação d'O Ateneu - pode-se compreender que o autor não tolerava fachadas, por isso descortina todas as informações encobertas. Essas posições extremadas do romancista culminam com o seu suicídio, sete anos após o lançamento da obra, o qual, provavelmente, foi motivado pela impossibilidade de manter o que ele considerava ser sua honra ao tentar responder ao ataque de Luís Murat, que o havia acusado de covarde, e não encontrar nenhum jornal que aceitasse publicar a resposta. Raul Pompeia, uma figura militante, que não aceitava injustiças, ao se ver injustiçado e humilhado por um antigo amigo, matou-se no Natal com um tiro no coração.

A motivação que levou Raul Pompeia a escrever O Ateneu talvez nunca seja desvendada. Mas, é conveniente pensar que em uma tentativa de registrar parte de sua vida, de forma romanceada, e de fazer uma crítica social ao Império brasileiro, simultaneamente, o romancista deixou sua marca na história da literatura brasileira. Detentor de um estilo vigoroso de escrita, cumulada de impressionismos, fez uso eloquente, daquilo que Barthes classificou posteriormente como "biografemas", de modo que deixou um texto literário cheio de obscuridades e ambiguidades para a crítica literária desvendar. Assim, 0 
Ateneu, cercado de mistérios, resiste ao tempo e se erige como uma das grandes obras da literatura brasileira.

\section{Referências}

ANDRADE, M. Aspectos da Literatura Brasileira. 5 Ed., São Paulo: Livraria Martins Editora S.A., 1943.

BARTHES, R. Inéditos, Vol. 2: Crítica. São Paulo: Editora Martins Fontes, 2004. . Roland Barthes por Roland Barthes. Barcelona-Espanha: Editorial Kairós, 1978.

BOSI, A. Céu, Inferno. 3 Ed., São Paulo: Editora 34, 2010.

Editora Cultrix, 1999.

História concisa da literatura brasileira. 34 ed., São Paulo:

BRANDÃO, R. de O. O Ateneu e a retórica. Remate de Males, Vol. 15, Campinas, 1995.

CAPAZ, C. Raul Pompeia Biografia. São Paulo: Ediouro, 2001.

COUTINHO, E. F. C. Raul Pompeia. Foz do Iguaçu-PR :EDUNILA, 2016.

DUCROT, O. \& TODOROV, T. Diccionario Enciclopédico de Ciencias del Lenguaje. Buenos Aires: Siglo XXI Editores, 1974.

FORSTER, E. M. ASPECTOS DA TEORIA DO ROMANCE. 2 Ed., Porto Alegre: Editora Globo, 1974.

GOLDMANN, L. Sociologia do romance. 2 d., Rio de Janeiro: Editora Paz e Terra, 1976.

LEJEUNE, P. O Pacto Autobiográfico De Rousseau à Internet. 2 Ed., Belo Horizonte Editora UFMG, 2014.

LUCAS, F. As várias faces de Raul Pompeia e O Ateneu. Remate de males. UNICAMP, Vol. 15, 1995, p.13-31.

LUKÁCS, G. A teoria do romance. São Paulo: Editora 34, São Paulo, 2000.

MOISÉS, M. História da literatura brasileira. São Paulo: Editora Cultrix, Vol. III, 1985.

PELK, S. M. P. Raul Pompeia: a natureza o denomina crítico de arte. Anais do III Encontro de Pesquisas Históricas - PPGH/PUCRS. Porto Alegre, 2016. 
p.305-314. Disponível em <http://www.ephispucrs.com.br > Acesso em: 04 de dezembro de 2017

POMPÉIA, R. O Ateneu. 16 Ed. São Paulo: Ática, 1996.

RIBEIRO, J. A. R. Raul Pompeia e a ficção nos jornais: ironia, humor e visualidade. Revista USP, São Paulo, no 72, p. 129 - 142, Dezembro/ Fevereiro $2006-2007$.

STEGAGNO-PICCHIO, L. História da Literatura Brasileira. 2. ed. Rio de Janeiro: Nova Aguilar, 2004. 